\title{
Air pollution and management in the Niger Delta - emerging issues
}

\author{
M. A. Fagbeja ${ }^{1,2}$, T. J. Chatterton ${ }^{1}$, J. W. S. Longhurst ${ }^{1}$, \\ J. O. Akinyede ${ }^{2} \&$ J. O. Adegoke ${ }^{3}$ \\ ${ }^{I}$ Air Quality Management Resource Centre, \\ University of the West of England, Bristol, UK \\ ${ }^{2}$ National Space Research and Development Agency (NASRDA), \\ Abuja, Nigeria \\ ${ }^{3}$ University of Missouri - Kansas City (UMKC), Missouri, USA
}

\begin{abstract}
This paper considers the various sources of air pollution in the Niger Delta and reviews some of the possible management strategies available to the authorities. The identified sources include burning of fossil fuels for transportation and industrial power generation, use of fuel wood and kerosene for domestic cooking and lighting, and gas flaring and are a function of urbanisation and industrialisation in an oil rich environment. The level of pollution due to gas flaring is considered. Gas flaring in the region is identified as one of the main sources of both $\mathrm{CO}_{2}$ and $\mathrm{CO}$, and it is expected to be a major contributor to NOx, and NMVOC concentrations in the Niger Delta. Challenges confronting air quality and carbon management in Nigeria are highlighted. Finally, an introduction to the National Space Research and Development Agency (NASRDA) funded research on air quality and carbon management in the Niger Delta is presented.
\end{abstract}

Keywords: air pollution, Niger Delta, gas flaring, remote sensing, GIS.

\section{Introduction}

Pollution is defined by the European Union 1996 Council Directive on Integrated Pollution Prevention and Control (IPPC) as "the direct or indirect introduction as a result of human activity, of substances, vibrations, heat or noise into the air, water or land which may be harmful to human health or the quality of the environment, 
result in damage to material property, or impair or interfere with amenities and other legitimate uses of the environment" [1]. Inorganic and organic air pollutants cause negative health and environmental effects such as respiratory ailments, premature deaths. Air pollution-related deaths worldwide are estimated to be up to 2 million per annum [2]. Other environmental consequences of air pollution include acidification of soil and water and loss of plant and animal life.

Air quality assessment studies in Nigeria have focused mainly on urban centres where industrial processes, domestic activities and traffic congestion constitute major sources of air pollution [3-5]. Most of these studies are independent as there are no systematic measurements of air quality by the government [3]. Measurements from selected dumpsites, industrial estates and heavy traffic stations in Lagos revealed that average concentrations of carbonmonoxide (CO) in heavy traffic stations was $49.32 \mathrm{ppm}$, while at industrial estates was $36.75 \mathrm{ppm}$ and at dumpsites, $10.76 \mathrm{ppm}$. Sulphur dioxide $\left(\mathrm{SO}_{2}\right)$ averages were $0.166 \mathrm{ppm}$ at the traffic stations, and $0.670 \mathrm{ppm}$ levels were detected at both industrial and dumpsites. The $\mathrm{NO}_{\mathrm{X}}$ concentrations were $0.220 \mathrm{ppm}$ at the dumpsites and $0.333 \mathrm{ppm}$ at both industrial and traffic stations [3]. WHO standards for $\mathrm{CO}, \mathrm{SO}_{2}$ and $\mathrm{NOx}$ are $5 \mathrm{ppm}$ for 8-hour average, $0.45 \mathrm{ppm}$ for 24 -hour average and $0.25 \mathrm{ppm}$ for 24 -hour average respectively [6]. These results clearly suggest that there are air quality problems arising from transportation, industrial and domestic activities and waste disposal in Nigeria. Another identified source of significant air pollution in Nigeria is gas flaring [7], which occurs mostly in the rural communities of the Niger Delta region of Nigeria, where majority of the oil and gas exploration takes place. However, there is little currently known about the impact of gas flaring due to a paucity of emissions measurements in the region. Considering the existence of gas flaring in the region since the 1950s when oil and gas exploration commenced in the region, it is expected that many studies should have been carried out on the extent of pollution from the activity. However, this is not the case. Shell Petroleum Development Corporation (SPDC) in its 2006 Annual report [8] stated that the oil industry submitted a proposal to the oil industry regulatory body, the Department of Petroleum Resources (DPR) for air quality assessment in the Niger Delta only in 2006. This effort to assess air quality in the Niger Delta came after five decades of oil exploration, and gas flaring, in the region.

The Niger Delta is located in the southern part of Nigeria. The region suffers from human and environmental issues of both national and international concern, in terms of the environmental pollution; impoverishment of the local people despite the wealth being generated from the region; security of human lives; property and infrastructure due to militancy; community agitations and youth unrest. This paper gives a brief description of the Niger Delta environment. It also highlights the major anthropogenic activities resulting in air pollution in the Niger Delta which include transportation, burning of fossil fuels for industrial and domestic use and waste disposal. Whilst the focus of the paper is on air pollution related to emissions from oil production, with specific emphasis on gas flaring, the challenges of air quality management in Nigeria as a whole are considered. 


\section{The Niger Delta}

The Niger Delta is formed as a result of the splitting up of the 4,100km-long Niger River [9] into estuaries through which it flows into the Atlantic Ocean at the Gulf of Guinea. There have been various definitions of the size of the Niger Delta based on hydrological, ecological and political boundaries [8, [10-13]. These definitions give an estimated range of the area covered by the Niger Delta from between $19,100 \mathrm{~km}^{2}$ and $30,000 \mathrm{~km}^{2}$. For this paper, the Niger Delta is defined by the area covered by oil producing states in Nigeria [10]. As such, the Niger Delta comprises of nine states out of the thirty-six states of the Nigerian Federation, namely Abia, Akwa-Ibom, Bayela, Cross-River, Delta, Edo, Imo, Ondo and Rivers. In view of this, the Niger Delta covers an estimated area of $110,445.98 \mathrm{~km}^{2}$ (figure 1). The Niger delta is a coastal lowland that consists of ecological zones of both vast fresh water swamps and mangrove forests, covering estimated areas of $11,700 \mathrm{~km}^{2}$ and $6,000 \mathrm{~km}^{2}$ respectively [11]. The region is rich in crude petroleum and natural gas reserves, one which makes it the twelfth richest petroleum province in the world [14]. Nigeria's oil and gas reserves are estimated to be 35.9 billion barrels and 185 trillion cubic feet respectively, making them the largest oil and gas reserves in Sub-Saharan Africa [15].

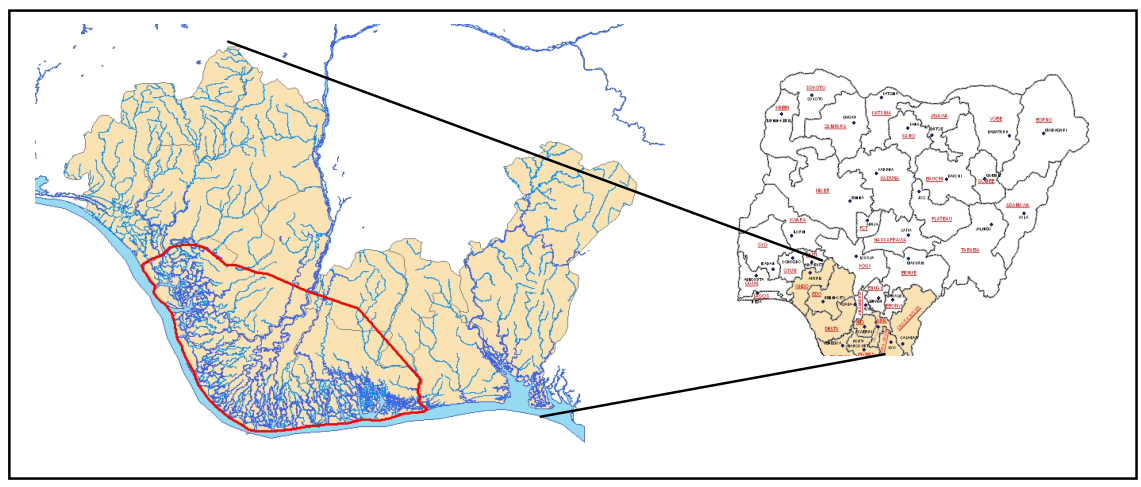

Figure 1: $\quad$ Map showing the approximate area defined as Niger Delta $[10,12]$ Source: Map derived from NASRDA data.

\section{Air pollution in the Niger Delta}

Air pollution in the Niger Delta has been on the increase since the commencement of oil and gas exploration in the region. The underlying factors responsible for air pollution in the Niger Delta are industrialisation, a general high rate of urbanisation that is unaccompanied with commensurate economic growth in Africa [16]; and poverty. The high rate of urbanisation with the attendant low growth is responsible for the level of urban poverty and inadequacies of infrastructure or amenities such as power and clean fuel for 
domestic use in African urban centres including those in the Niger Delta. The United Nations Human Development Report for 2007-2008 indicated that $92.4 \%$ of Nigerians lived below the income poverty line of $\$ 2$ a day [17]. In the Niger Delta region, $66.1 \%$ of the population self-classify themselves as poor [18].

\subsection{Sources of air pollution in the Niger Delta}

Due to lack of infrastructure for providing clean energy to homes and poverty, majority of both the rural and urban populace in the Niger Delta depend on the use of fuel wood and kerosene for domestic cooking and lighting. This results in indoor air pollution and also contributes to ambient air pollution [19]. NOx and $\mathrm{CO}$ from these sources result in an estimated 79,000 deaths a year in Nigeria [20]. The Nigerian National Bureau of Statistics (NBS) identifies $70.0 \%$ of Nigerians rely on firewood for cooking. $26.6 \%$ depend on the use of kerosene or oil, while $0.52 \%$ and $1.11 \%$ use electricity and gas respectively [21].

Burning of fossil fuels for transportation in the inland urban and rural centres of the Niger Delta is another major source of air pollution in the region. The majority of Nigerians can not afford new vehicles due to prohibitive costs and, as a result, depend on vehicles which are older than the majority of cars used in Europe. Such vehicles can emit five times more hydrocarbons and carbon monoxide and four times more nitrogen oxides than vehicles commonly found in developed countries [22].

Due to the presence of the oil industry in the Niger Delta, as well as the region's proximity to the ocean, many industries are located in the main urban centres of Port Harcourt, Warri and Aba. In addition, there is oil and gas related activities in many rural, riverine areas where most of the oil fields are located. Nigeria achieved a $46 \%$ electrification rate between 2000 and 2005, with an estimated 71.1 million people out of the estimated total 2005 population of 141.4 million without access to electricity [17]. Electricity supply in Nigeria has dropped even lower in recent times due to poor management and vandalism of existing power generation, transmission and distribution infrastructure. Consequently, most industries in the Niger Delta depend on the use of dieselfuelled generators. Some rural communities also depend solely on use of an industrial generator for electricity supply, due to non-connection to the national grid. For example, in Burutu, a riverine community in Delta State, the local government administrator provided an industrial generator to supply electricity to the community between $6 \mathrm{pm}$ and $6 \mathrm{am}$ daily. The majority of the community dwellers could not afford to buy personal generators.

The contributions of household and industrial emissions of particulates, NOx and non-methane volatile carbon (NMVOC) have been assessed in selected cities and state of the Niger Delta by Ajao \& Anurigwo (2002) [4]. The results show that Port Harcourt city accounts for a high concentration of particulates, NOx and NMVOC. The emissions from Port Harcourt city are greater than the total emissions from an entire state (Delta State) (Table 2). This is an indication of the relatively high level of urbanisation and industrialisation of the city. The projected population of Port Harcourt for 2008 is 1,899,372 [23]. Together with 
Table 1: Total air emissions from industry and households in Port Harcourt, Delta State and Calabar. Source: [4].

\begin{tabular}{|l|l|l|l|}
\hline Location/Source & $\begin{array}{l}\text { Particulates } \\
\text { tonnes yr }^{-1} \text { ) }\end{array}$ & $\begin{array}{l}\text { NOx } \\
\text { (tonnes yr }^{-1} \text { ) }\end{array}$ & $\begin{array}{l}\text { NMVOC } \\
\text { (tonnes yr }^{-1} \text { ) }\end{array}$ \\
\hline $\begin{array}{l}\text { Port Harcourt } \\
\text { - Trans Amadi Industrial Area, including } \\
\text { NAFCON and refinery, exclusive of } \\
\text { solvents. } \\
\text { - Industries and households }\end{array}$ & $\begin{array}{l}10,496 \\
\text { Not available }\end{array}$ & $\begin{array}{l}779 \\
\text { Not available }\end{array}$ & $\begin{array}{l}292 \\
3,775\end{array}$ \\
\hline $\begin{array}{l}\text { Delta State } \\
\text { - Industries in Delta } \\
\text { - Solvents, small industries and households }\end{array}$ & 760.84 & 384.41 & $1,047.7$ \\
$\begin{array}{l}\text { Warri } \\
\text { - Industries }\end{array}$ & Not available & $\begin{array}{l}\text { Not } \\
\text { available }\end{array}$ \\
- Solvents, small industries and households & $\begin{array}{l}35.43 \\
1,593.3\end{array}$ & $\begin{array}{l}\text { Not available } \\
\text { Not } \\
\text { available }\end{array}$ \\
\hline
\end{tabular}

Warri, Port Harcourt serves as the operational base for most of the multinational and local oil companies in Nigeria.

\subsection{Pollution from gas flaring in the Niger Delta}

Since June 1956 when commercial oil exploration started at Oloibiri in Bayelsa State, the gas associated with the oil production has been flared. In 1970, 99\% of the gas produced in Nigeria was flared (figure 2). This reduced to an estimated $72 \%$ in 1997 , even though the volume steadily increased between 1970 and 1996 [24]. Due to efforts by the Nigerian government at utilising the associated gas through the development of liquefied natural gas (LNG) plant in Bonny, supply to industries and electricity generation, the volume of gas flared in Nigeria reduced to approximately 23.0 million cubic meters $(812.24$ billion cubic feet (BCF)), representing 39\% of total gas produced in 2004/2005 [18].

In Nigeria, gas flaring contributed an estimated 12.7 million metric tonnes of carbon in 2004 through $\mathrm{CO}_{2}$ emissions. This represents $41 \%$ of the estimated total $\mathrm{CO}_{2}$ emissions in Nigeria [25]. In 1995, the total $\mathrm{CO}$ emission from Nigeria was $21.42 \mathrm{Tg} / \mathrm{yr} \mathrm{CO}$, with gas flaring in the Niger Delta being the third main contributor after combustion of bio-fuels and agriculture. Gas flaring contributed estimated $2.49 \mathrm{Tg} / \mathrm{yr} \mathrm{CO}$ representing $12 \%$ of total $\mathrm{CO}$ emissions in Nigeria in 1995 [26]. Other pollutants from gas flaring include sulphur dioxide, nonmethane volatile organic carbons (NMVOC), nitrogen oxides and methane. The quantities of emissions of these pollutants from gas flaring in Nigeria are yet to be ascertained due to unavailability of data. It is, however, expected that gas 
flaring in the Niger Delta will be the major single contributor of the emissions of these pollutants into the Nigerian atmosphere.

\section{Challenges of air pollution management in Nigeria}

The Nigerian government identifies emissions of $\mathrm{CO}_{2}$ and other green house gases (GHGs) that contribute to climate change as an environmental problem [27]. However, the report did not include air quality as part of the environmental concerns for the Nigerian government. This could explain the unavailability of consistent emissions inventory for the country. Although there has been some independent research into air quality assessment in parts of Nigeria [5], more needs to be done by the Nigerian regulatory bodies to systematically enforce regulations aimed at improving air quality in Nigeria. The Federal Environmental Protection Agency (FEPA) was established under the Amended decree No. 59 of 1992 in the Laws of the Federation of Nigeria to undertake the following among other things [28]:

- prepare a comprehensive national policy for the protection of the environment and conservation of natural resources, including procedures for environmental impact assessment for all development projects;

- $\quad$ prepare, in accordance with the National Policy on the Environment, periodic master plans for the development of environmental sciences and technology and advise the Federal Military Government on the financial requirements for the implementation of such plans;

- promote co-operation in environmental science and conservation technology with similar bodies in other countries and with international bodies connected with the protection of the environment and the conservation of natural resources;

- co-operate with Federal and State Ministries, Local Governments, statutory bodies and research agencies on matters and facilities relating to the protection of the environment and the conservation of natural resources.

Consequently, FEPA established the National Air Quality Standards (NAQS) in Nigeria in 1991 (table 3) [29].

Some of the practices employed by FEPA and the Nigerian Federal Ministry of Environment (FMEnv) are the imposition of emission taxes, and the enforcement of emission abatement control mechanisms by industries. For example, the Federal Government of Nigeria recently increased gas flaring tax on oil companies in the Niger Delta. The new tax regime is $\$ 3.50$ (about $£ 1.75$ ) on every 1,000 standard cubic feet of gas flared, representing an estimated $4,000 \%$ increase from the previous charge of about $\$ 0.08$ (about $£ 0.04$ ), which had been in effect since the early 1960s [30]. In 1996, FEPA closed down an iron and steel company in Lagos for failing to implement measures to reduce emissions from its furnace [31]. However, enforcement has been one of the key issues confronting air pollution control in Nigeria. Many industries contributing to air pollution, such as the oil refineries and National Fertiliser Company 
(NAFCON) are being run by the government, although in recent times, efforts are being made to privatise them, with the Government still holding some percentage of the shares. These companies often escape sanctions from government regulatory agencies and as a result, there is limited consideration of pollution control measures in these industries.

Table 2: $\quad$ National Air Quality Standards (NAQS) in Nigeria. Source: [29].

\begin{tabular}{|c|c|c|}
\hline Pollutants & Ambient Limits & $\begin{array}{l}\text { Limit from stationary } \\
\text { sources (For } 24 \mathrm{hrs)}\end{array}$ \\
\hline Particulates & $\begin{array}{l}250 \mu \mathrm{g} / \mathrm{m}^{3} \text { (Daily average of daily } \\
\text { values } 1 \text { hour) }\end{array}$ & $0.15-0 . \mathrm{mg} / \mathrm{m} 3$ \\
\hline Sulphur Dioxides $\left(\mathrm{SO}_{2}\right)$ & 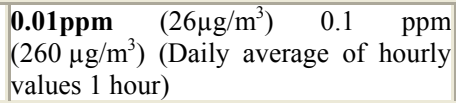 & $0.05-0.5 \mathrm{mg} / \mathrm{m}^{3}$ \\
\hline Non-methane hydrocarbon & $\begin{array}{l}160 \mu \mathrm{g} / \mathbf{m}^{3} \text { (Daily average of 3-hourly } \\
\text { values) }\end{array}$ & $2.0-5.0 \mathrm{mg} / \mathrm{m}^{3}$ \\
\hline Carbon monoxide & $\begin{array}{l}\text { 10ppm }\left(11.4 \mathrm{mg} / \mathrm{m}^{3}\right) \quad 20 \quad \mathrm{ppm} \\
\left(22.8 \mu \mathrm{g} / \mathrm{m}^{3}\right) \text { (Daily average of hourly } \\
\text { values } 8 \text {-hours) }\end{array}$ & $1.0-5.0 \mathrm{mg} / \mathrm{m}^{3}$ \\
\hline Nitrogen Oxides (NO2) & $\begin{array}{l}\text { 0.04ppm }-\mathbf{0 . 0 6} \text { ppm }(75.0- \\
\left.113 \mathrm{mg} / \mathrm{m}^{3}\right) \text { Daily average of } 1 \text { 1-hourly } \\
\text { values }(\text { range })\end{array}$ & $0.004-0.1 \mathrm{mg} / \mathrm{m}^{3}$ \\
\hline Photochemical Oxidant & 0.06ppm (Hourly values) & 5133.0ppm \\
\hline
\end{tabular}

NAFCON produces $\mathrm{SO}_{2}$ as a by-product. The company allows sulphur wastes to be emitted as $\mathrm{SO}_{2}$ instead of converting the waste to a more useful sulphuric acid, since the company escapes payment of charges or taxes on the emissions [32].

Another major limitation to air pollution and carbon management in Nigeria is the lack of data on concentrations of the major air pollutants and greenhouse gases (GHGs) in Nigeria. From the World Data Centre for Greenhouse Gases (WDCGG) website, Nigeria has no monitoring stations that contribute to data on concentrations of GHGs $\left(\mathrm{CO}_{2}, \mathrm{CH}_{4}, \mathrm{CFCs}, \mathrm{N}_{2} \mathrm{O}\right.$ and surface $\left.\mathrm{O}_{3}\right)$ and other air pollutants (CO, NOx, $\mathrm{SO}_{2}$, and VOCs). The WDCGG collects data under the World Meteorological Organisation's (WMO) Global Atmospheric Watch (GAW) and other programmes [33]. This clearly suggests that the regulatory ministry and agencies in Nigeria - the Federal Ministry of Environment (FMEnv), Federal Environmental Protection Agency (FEPA) and the Nigerian Meteorological Agency (NIMET) - do not measure concentrations of air pollutants and GHGs on a systematic and consistent basis that would enable a nationwide assessment of the air quality situation in the country upon which proper legislation and efforts will be based at achieving clean air in Nigeria. There may be independent (e.g. oil industry) and/or research-based (universities and research institutions) measurements, but these are not readily available to the general public. This limitation necessitates and justifies the consideration of the use of satellite data in conjunction with independent in-situ measurements of air quality and carbon parameters for this research in order to apply remote sensing 
and GIS techniques to air quality and carbon management, a case study of gas flaring in the Niger Delta. The research is being funded by the Nigerian National Space Research and Development Agency (NASRDA).

\section{Conclusions}

Air pollution in the Niger Delta region is an issue that requires attention by the Nigerian authorities and operators of the oil and gas industry because it has been occurring for a long time without proper control and management. The Nigerian authorities need to fully explore the potentials for gas utilisation in Nigeria. Efforts should be intensified to ensure that hitherto flared gas is used to provide adequate power generation for the nation. Gas pipelines should be laid across the major industrial areas of Nigeria to supply gas for the running of industries. This will reduce industrial dependence on burning of liquid and solid fossil fuels for energy and ensure the use of cleaner fuels for running industrial operations in Nigeria. In addition, there is need for the development of a robust monitoring and management system, which ensure that high quality information on the extent and impact of air pollution can be used as the basis for legislation to curtail the pollution and develop a mechanism that will enhance clean air when gas flaring ends in Nigeria. The Nigerian government intends to phase out gas flaring in the Niger Delta in the near future. In view of this, the Nigerian National Space Research and Development Agency (NASRDA) is funding the research titled, "Applying remote sensing and GIS techniques to air quality and carbon management, a case study of gas flaring in the Niger Delta." The research, which commenced in January 2008 at the University of the West of England, aims to integrate in-situ measurements of ambient concentrations and emissions with satellite remote sensing data to assess air quality emissions and $\mathrm{CO}_{2}$ concentrations resulting from gas flaring in the Niger Delta. The available satellite technology resources at NASRDA will combine with the European expertise in air quality studies available at UWE to proffer solutions to air pollution and air quality management in the Niger Delta.

\section{References}

[1] IPPC, Council Directive 96/61/EC of 24 September 1996 concerning integrated pollution prevention and control. Official Journal L 257, 10/10/1996 P. $0026 \quad$ - 0040. 1996. Online: http://eurlex.europa.eu/LexUriServ/LexUriServ.do?uri=CELEX:31996L0061:EN:H TML.

[2] World Health Organisation, WHO, Reducing risks, promoting healthy life. The World Health Report 2002. Geneva. 2002. Online. http://www.who.int/whr/2002/en/whr02_en.pdf.

[3] Taiwo, O., The case of Lagos - air quality improvement project. Presentation for the Lagos Metropolitan Area Transport Authority. 2005 Online. www.cleanairnet.org/ssa/1414/articles-69320_Taiwo.pdf. 
[4] Ajao, E.A. \& Anurigwo, S., Land-based sources of pollution in the Niger Delta, Nigeria. Ambio, 31, pp. 442-445. 2002.

[5] Baumbach, G., Vogt, U., Hein, K.R.G., Oluwole, A.F., Ogunsola, O.J., Olaniyi, H.B., and Akeredolu, F.A., Air pollution in a large tropical city with high traffic density - results of measurements in Lagos, Nigeria. The Science of the Total Environment, 169, pp. 25-31. 1995.

[6] World Bank, Air Quality Standards. 1995 Online. http://www.worldbank.org/html/fpd/em/power/standards/airqstd.stm\#who

[7] Isuwa, S., Nigeria: transportation, major cause of air pollution. Report of the Director General of National Environmental Standards and Regulations Enforcement Agency (NESREA) at a seminar on WHO Air Quality Guidelines. 2008. Online: www.allafrica.com/stories/200804040160.html.

[8] Shell Petroleum Development Corporation, SPDC, People and the environment. Shell Nigeria Annual Report 2006. Shell Visual Media Services, London. 2006.

[9] FAO, Irrigation potentials in Africa: a basin approach. FAO Land and Water Bulletin - 4. FAO Land and Water Development Division, Rome. 1997.

[10] United Nations Development Programme (UNDP), Niger delta human development report. UNDP, Abuja, Nigeria 2006.

[11] Moffat, D. \& Linden, O., Perception and realities: assessing priorities for sustainable development in the Niger River delta. Ambio, 24, pp. 527-538. 1995

[12] ERML, Environmental and socio-economics characteristics of the Niger Delta. Niger Delta Environmental Survey Report. 1997

[13] Abam, T.S.K., Regional hydrological research perspectives in the Niger Delta. Hydrological Sciences, 46, pp. 13-25. 2001

[14] Klett, T.R., Ahlbrandt, T.S., Schmoker, J.W., and Dolton, J.L., Ranking of the world's oil and gas provinces by known petroleum volumes. U.S. Geological Survey Open-file Report-97-463. 1997.

[15] Library of Congress, Federal Research Division, Country Profile: Nigeria. Published June 2006, pp. 12-13, 21-22. 2006.

[16] Hicks, F.J., Enhancing the productivity of urban Africa. International Conference on Research Community for the Habitat Agenda Forum of Researchers on Human Settlements. Geneva., July 6-8, 1998. Online. http://wbln0018.worldbank.org:80/External/Urban/UrbanDev.nsf/Urban+D evelopment/06FCBF7D26772E6885256B18007BA532?OpenDocument.

[17] United Nations Development Programme (UNDP), UNDP human development report 2007/2008 - Fighting climate change: human solidarity in a divided world. UNDP, New York. 2007. Online. http://hdr.undp.org/media/hdr_20072008_en_complete_pdf.

[18] National Bureau of Statistics, (NBS), The Nigerian statistical fact sheets on economic and social development. National Bureau of Statistics, Abuja. 2006. 
[19] Anozie, A.N., Bakare, A.R., Sonibare, A.J., and Oyebisi, T.O., Evaluation of cooking energy cost, efficiency, impact on air pollution and policy in Nigeria. Energy, 32, 1283-1290. 2007.

[20] World Health Organisation (WHO), Country profiles on environmental burden of disease. Geneva, 2007. Online: http://www.who.int /quantifying_ehimpacts/countryprofilesafro.pdf

[21] National Bureau of Statistics (NBS), Poverty profile for Nigeria. Abuja. 2005.

[22] United Nations Environment Programme (UNEP), Global environmental outlook 2000. Nairobi. (2000). Online: http://www.unep.org/Geo/geo2000.

[23] World Gazetteer, Nigeria: largest cities and towns and statistics of their population. 2008. Online: http://www.world-gazetteer.com

[24] Ukoli, M.K., Environmental factors in the management of the oil and gas industry in Nigeria. 2001. Online: http://www.cenbank.org /OUT/PUBLICATIONS/OCCASIONALPAPERS/RD/2001/OWE-012.PDF

[25] Marland, G., Boden, T. and Andres, R. J., Global, regional, and national $\mathrm{CO}_{2}$ emissions. Trends: A Compendium of Data on Global Change. Carbon Dioxide Information Analysis Centre, Oak Ridge National Laboratory, U.S.A 2007. Online. http://cdiac.ornl.gov/ftp/ndp030 /nation.1751_2004.ems

[26] Global Emissions Inventory Activity, GEIA, Source grouping in country summary tables. 2004. Online: http:/www.mnp.nl/geia/data /Carbon_Monoxide/Documentation.jsp

[27] Adeyinka, M.A., Bankole, P.O., and Olaye, S., Environmental Statistics: situation in Federal Republic of Nigeria. Country report presented at the Workshop on Environmental Statistics, Dakar, Senegal, from $28^{\text {th }}$ February $-4^{\text {th }}$ March 2005.

[28] Federal Republic of Nigeria, Constitution of the Federal Republic of Nigeria 1999. Online: http://www.nigeria-law.org/Federal\%20 Environmental\%20Protection $\% 20$ Agency $\% 20$ (Amendment) $\% 20$ Decree $\% 2$ 0No.\%2059\%201992.htm

[29] Federal Environmental Protection Agency (FEPA), National interim Guidelines and Standards for Industrial effluents, Gaseous emissions and Hazardous wastes. Environmental Pollution Control Handbook. Lagos, FEPA. 1991.

[30] Ibiyemi, S., FG approves N410/scf gas-flaring fee. Financial Standard Newspaper, 13 May 2008. Financial Standard, Lagos. 2008. Online. http://www.financialstandardnews.com/

[31] Izeze, E.M., FEPA to inspect CISCO. The Guardian Newspapers, $22^{\text {nd }}$ April 1996. Lagos. 1996

[32] Uchegbu, S.N., Environmental management and protection. Precision Printer and Publishing, Enugu. 1998.

[33] World Meteorological Organisation, WMO, WMO Global Atmospheric Watch: World Data Centre for Greenhouse Gases (WDCGG). 2001. Online: http://gaw.kishou.go.jp/wdegg/ 